\title{
Słownictwo pism Stefana Żeromskiego, t. 1-7, pod. red. K. Handke,
}

Kraków 2002

Słownictwo pism Stefana Żeromskiego jest rezultatem pracy zespołu badaczy pracującego pod kierunkiem Kwiryny Handke. Na publikację składa się seria sześciu autorskich tomów monografii: Katarzyny Sobolewskiej Przestrzeń, Elżbiety Sękowskiej Dom, Barbary Bartnickiej Świat dźwięków, Kwiryny Handke Świat barw, Ryszarda Handkego Walka, wojna, wojskowość, Henryki Sędziak Myśl i mowa. Całość poprzedza Tom wstępny opracowany przez Kwirynę Handke.

Wobec ciągle nieukończonej nowej edycji Pism zebranych Stefana Żeromskiego (pod red. Zbigniewa Golińskiego) zdecydowano się przyjąć jako kanon tekstów pisarza dwa krytyczne wydania w opracowaniu Stanisława Pigonia, tj. Pisma, tomy I-XXIII i XXVI (Warszawa 1947-1956) lub Dzieła I. Nowele i opowiadania, tomy 1-5; II. Powieści, tomy 1-14; III. Dramaty, tomy 1-4; IV. Pisma różne, tomy 1-2; V. Dzienniki, tomy 1-7 (Warszawa 1956-1970). Ponadto Dzienniki, tomy I-III (Warszawa 1953-1956) oraz Dzienników tom odnaleziony (Warszawa 1973) ${ }^{1}$.

Chęć lepszego i bardziej wyrazistego zróżnicowania materiału oraz spojrzenia przez pryzmat słownictwa nie tylko na właściwości stylu artystycznego poszczególnych utworów, ale także i na świat $\mathrm{w}$ nich przedstawiony oraz jego realia skłoniła twórców słownika do poszukiwania innego rozwiązania niż pełny słownik pisarza, a więc nie takiego, jakie przedstawiają Stownik języka J. Ch. Paska (red. H. Koneczna i W. Doroszewski), Stownik Języka A. Mickiewicza (red. K. Górski, S. Hrabec, Słownik polszczyzny Jana Kochanowskiego (red. M. Kucała), który obej-

1 Każdy $z$ autorów monografii mógł się zdecydować na jedno $z$ dwu wydań zbiorowych dziet Stefana Żeromskiego, zaznaczając $w$ swoim opracowaniu, które $z$ nich uczynit podstawa do ekscerpcji materiału. Por. K. Handke, Słownictwo pism Stefana Żeromskiego. Tom wstępny, Kraków 2002, s. 19. 
muje tylko dzieła polskie pisarza, czy też Słownik języka Cypriana Norwida (red. J. Puzynina).

Za najlepszą formę realizacji takiej koncepcji opracowania uznano więc serie autorskich monografii poświęconych określonym kręgom tematycznym słownictwa, wydobytego z prawie całej drukowanej spuścizny Stefana Żeromskiego. Tym samym powstała formuła otwarta dla następnych autorów, którzy w przyszłości będą mogli tworzyć kolejne monografie tematyczne słownictwa Żeromskiego i powiększą obecną serię opracowań ${ }^{2}$. Będzie to o tyle łatwiejsze, że w Tomie wstępnym, K. Handke zamieszcza Instrukcję redakcyjnq do słownika, w której podaje obowiązujące w nim zasady ogólne i zasady szczegółowe.

Przedstawia zatem kanon tekstów i podstawę materiałową, chronologiczny wykaz wykorzystanych tekstów St. Żeromskiego (według dat ich pierwszych wydań), fragmenty wypowiedzi Żeromskiego o języku, literaturę przedmiotu. Autorka przypomina dzieje pomysłu i jego realizację, mówi o metodach i zasadach opracowania materiału.

Zgodnie z przyjętym założeniem, każdy tom serii monografii tematycznych składa się z dwóch części: słownikowej i interpretacyjnej. Część słownikowa zawiera wyczerpujący zbiór leksyki mieszczącej się $\mathrm{w}$ obrębie danego kręgu tematycznego (np. dom, przestrzeń, czy świat barw). $\mathrm{Z}$ zasady materiał $\mathrm{w}$ tej części opracowania jest ułożony $\mathrm{w}$ ciągu alfabetycznym, chociaż zdarza się, iż dla większej przejrzystości przedstawienia pojawia się układ gniazdowo-alfabetyczny ${ }^{3}$. W dodatkowych aneksach układ haseł bywa alfabetyczny, gniazdowy, gniazdowo-alfabetyczny lub według pól semantycznych. Część interpretacyjna zawiera charakterystykę zgromadzonego słownictwa. Pokazano je wielostronnie, a jednocześnie poprzez leksykę przedstawiono językowy obraz świata rzeczywistego, w którym żył pisarz oraz obraz świata przedstawionego $\mathrm{w}$ jego utworach.

$2 \mathrm{KBN}$ przyznał dotację na kontynuowanie prac badawczych nad tym tematem. Nowa seria monografii zostanie ukończona we wrześniu 2005 r. i obejmie następujące kręgi tematyczne: Świat doznań i wrażeń (autorstwa Barbary Bartnickiej); Świat roślin (Stanisława Cygana); Topografia (Magdaleny Czachorowskiej); Niebo i piekło (Moniki Gabryś); Kobieta (Kwiryny Handke); Mężczy$z n a$ (Ryszarda Handkego); Meteorologia i astronomia (Marii Olszewskiej); Miasto i wieś (Katarzyny Sobolewskiej).

3 Taki układ zastosowała K. Handke w tomie Świat barw, gdzie najważniejsze było uwypuklenie gniazd kolorów, ukazujących zakresy i obszary ich użycia w tekstach pisarza. 
Materiał obejmuje wyrazy samodzielne, głównie rzeczowniki, przymiotniki, przysłówki, czasowniki i imiesłowy oraz różne związki wyrazowe. Figury stylistyczne (rozbudowane przenośnie, porównania, tautologie, synestezje, ironia, kontrasty semantyczne itd.) są omawiane w częściach opisowych poszczególnych monografii tematycznych.

W całej serii przyjęto odrębną selekcję materiału dla każdej monografii, odpowiadająca opracowywanemu kręgowi tematycznemu, np. w pracy pt. Świat barw najważniejsze są przymiotniki i ich związki, głównie z rzeczownikami, a w tomie Myśl i mowa szerzej uwzględniono związki składniowe. Ważne są tu konteksty ilustrujące użycie poszczególnych jednostek słownikowych, dlatego nie stworzono jednolitych zasad ograniczających formę i rozległość cytowanych kontekstów, jakie obowiązują w typowych opracowaniach leksykograficznych.

Obowiązuje też zasada pełnej ekscerpcji wszystkich uwzględnionych jednostek słownikowych w danym kręgu tematycznym. Do słownika wprowadzono jednak tylko część zgromadzonych kontekstów ilustrujących poszczególne znaczenia jednostek słownikowych, ponieważ rozmiar zebranego materiału wykluczał jego pełne przytoczenie. Poza tym część materiału wykorzystano $w$ omówieniach konkretnych zjawisk stylistyczno-językowych oraz $\mathrm{w}$ charakterystyce utworów i kręgów tematycznych.

Informacje o frekwencji poszczególnych jednostek słownikowych w konkretnych utworach lub w całym korpusie tekstów nie są obligatoryjne, więc autorzy sami mogli decydować o ich przydatności. Podobnie, do uznania autorów pozostawiono podawanie danych etymologicznych oraz informacji o źródłach zapożyczeń.

Dla stwierdzenia, czy i w jakim zakresie badane słownictwo $\mathrm{z}$ tekstów Żeromskiego zostało włączone do ogólnopolskich leksykonów, przyjęto zasadę porównywania zgromadzonego materiału ze Słownikiem języka polskiego pod red. Witolda Doroszewskiego, którego zawartość odpowiada czasom, w których żył i tworzył St. Żeromski.

W każdym tomie monografii artykuł hasłowy obejmuje: hasło, tj. wyraz hasłowy $\mathrm{w}$ formie podstawowej, jego warianty fonetyczne, ewentualne warianty fleksyjne, kolejne objaśnienia znaczeń (od realnego do przenośnych, ewentualnie z odpowiednią liczbą użyć wyrazu hasłowego w każdym znaczeniu). 
Pod każdym znaczeniem zamieszczono cytaty (do pięciu) ilustrujące użycie wyrazu hasłowego, podano wykaz utartej frazeologii (łączliwość podano osobno przy każdym znaczeniu; łącznie zaś przy odcieniach znaczeniowych i użyciach kontekstowych, w podziale na wyrażenia, zwroty, frazy, podhasło, ewentualne dane etymologiczne oraz dodatkowe informacje wynikające $\mathrm{z}$ kwerendy słownikowej.

Katarzyna Sobolewska, analizująca $\mathrm{w}$ drugim tomie monografii ponad tysiąc rzeczowników związanych z przestrzenią ujmuje tę leksykę $\mathrm{z}$ różnych punktów widzenia. $\mathrm{W}$ planie artystycznym pokazuje nasycenie tekstów Żeromskiego słownictwem z tego zakresu. Na przykład $\mathrm{w}$ grupie nazw tworów przestrzennych, hasło obiekt obejmuje ok. 170 haseł, skupionych wokół 3 sfer znaczeniowych, zaś odcinek tylko 7 i hasła te są w większości terminami geometrycznymi: cięciwa, promień, szerokość, wysokość, długość, dystans, poczatek. Z kolei obszar to przestrzeń wyodrębniona na podstawie 4 różnych kryteriów i stanowi najliczniejszą grupę haseł - ok. 420 leksemów. Uwzględniając kryterium pojęciowe, autorka omawia słowa związane $\mathrm{z}$ pojęciem przestrzeni (miejsce $\mathrm{i}$ orientacje w przestrzeni, kierunek, odległość, ułożenie obiektów względem siebie, stany, miary, wymiary itd. W ujęciu stylistycznym skupia się na słownictwie, w tym leksyce przestarzałej, np. pogłowie, i gwarowej, jak: dalecyna, duchowina, krzyżowe, niewidok, osuch, pażyca, połanki, zawrocia. Analizuje słowa-klucze, używane również $\mathrm{w}$ znaczeniach metaforycznych, np.: głębia, padót, obszar, i inne zjawiska semantyczne, m.in. wyzyskiwanie wieloznaczności wyrazów, nacechowanie emocjonalne nazw przestrzeni, modyfikacje znaczeń wyrazu, frazeologię, składnię i łączliwość oraz metaforykę. Autorka podkreśla: „Metafory przestrzenne Żeromskiego niosą ze sobą ogromny ładunek ideowy i emocjonalny, ukazują kondycję człowieka w świecie tak, jak postrzegał ją Autor. Jest to wizja pesymistyczna. Człowiek doświadcza w życiu nieustannego braku rzeczy cennych, niezbędnych, pożądanych i cierpi na nadmiar zjawisk złych, niszczących, wypalających go wewnętrznie. Jest tragicznie skonfliktowany $\mathrm{z}$ samym sobą i pozbawiony punktu oparcia $\mathrm{w}$ jakimkolwiek systemie wartości. Nie panuje nad własnymi uczuciami i reakcjami. Bezskutecznie szuka porozumienia $\mathrm{z}$ innymi ludźmi. Jedyny sens $\mathrm{w}$ jego życiu może nadać ciężka i niedoceniona praca, która skazuje go zarazem na jeszcze większą biedę i samotność" (s. 23). 
Poza tym autorka wydobywa inne ważne właściwości analizowanego kręgu tematycznego takie, jak: przestrzeń zniewolona, przestrzeń podbitego kraju, obraz przedstawiający stan psychiczny patrzącego; aluzje przestrzenne umożliwiające czytelnikowi identyfikację geograficzną miejsca akcji, którego nazwę pominięto ze względów cenzuralnych; zajmuje się też zagadnieniami związanymi z psychologią twórczości.

Tom trzeci, autorstwa Elżbiety Sękowskiej, zawiera słownictwo dotyczące domu. Obejmuje ono: 1) wszystkie znaczenia leksemu dom, jak też leksemy wchodzące $\mathrm{w}$ relacje synonimii i homonimii $\mathrm{z}$ wyrazem dom - leksemy, w których realizuje się składnik definicyjny mający wartość odróżniającą, wskazującą na to, że wyraz występuje w znaczeniu 'budynek mieszkalny, jako miejsce pobytu, schronienie bohaterów, dom rodzinny, siedziba', także 2) leksemy, w których dominuje jeden zespół cech i te znajdują się na peryferiach pola, i także, w których łączy się kilka, te stanowią centrum pola, np. wyrazy, w których składnik dystynktywny wskazuje na typ budynku i użytkownika: chatupa 'chłopski dom mieszkalny, zwykle drewniany'; dwór 'obszerny dom mieszkalny należący do majątku ziemskiego, dawniej będący własnością dziedzica'; pałac 'budynek mieszkalny o charakterze reprezentacyjnym, pozbawiony cech obronnych, stanowiący rezydencję magnacką'; czy też willa, zamek, lepianka, ziemianka, wyrazy, w których składnik dystynktywny wskazuje na czasowość pobytu: hotel 'dom mieszkalny przeznaczony do czasowego pobytu osób', ale też: karczma, oberża, zajazd; leksemy, w których sens główny wskazuje na użytkownika: gajówka 'budynek, w którym mieszka gajowy' czy też: leśniczówka, plebania, probostwo; wyrazy, w których główny składnik semantyczny wskazúje na cechę wykonania: barak 'prowizoryczny budynek parterowy przeznaczony na tymczasowe mieszkanie'; buda 'budynek sklecony niestarannie z licznych materiałów'; dziura 'źle urządzony, zaniedbany lokal', ale też: rudera itd., 3) leksemy, które kontekstowo mają funkcję nazwy określającej 'siedzibę, miejsce udomowione, czasowo pełniące funkcję schronienia'; w tym sensie domem może być każda przyjazna i pożądana przestrzeń, np.: grota, jaskinia, pieczara, piwnica, podziemie, spelunka, a także sytuacje przenośne, np. grobowiec, grobowisko, grób; 4) leksemy, które realizują cechę udomowienia w sposób przenośny, np. metafory 
genetyczne: gniazdo (rodzinne), ognisko (domowe, rodzinne), w tym także metonimie: dach, próg(-i), strzecha, węgiet; a także frazeologizmy: moja strona (umiłowana); $w$ czterech ścianach, $w$ swoich ścianach, na własnych śmieciach, na swoich śmieciach; 5) dom jako wartość społeczno-kulturowa, tzn. 'siedziba grupy społecznej, połączonej więzami rodzinnymi, przechowującą i przekazującą wartości życia rodzinnego, styl życia, obyczajowość, zwyczaje, poglądy religijne i patriotyczne, miejsce integracji rodziny, znajomych, domowników itd. Cechy te realizowane są kontekstowo: Dom konotuje utrwalane społecznie treści takie, jak: bliskość, bezpieczeństwo, ład, porządek, dostatek, intymność, przytulność, tożsamość poprzez przekazywanie tradycji, obyczaju, stylu życia. W takim ujęciu dom to wartość społeczna i kulturowa (ta cecha nie jest uwzględniona $\mathrm{w}$ definicjach słownikowych), jest ona podłożem metafor, używanie wyrazu dom w znaczeniu przenośnym ojczyzny, ojcowizny, gniazda rodzinnego itd. W łączliwość z rzeczownikiem dom wchodzą wyrazy semantycznie lub konotacyjnie wartościujące, a zatem nacechowanie aksjologiczne bada się w kontekstach i charakterystycznych opozycjach (np. dom czyli ojczyzna, dom czyli dostatek, dom czyli ład, porzqdek).

W prezentowanym słowniku szczególne miejsce zajmują wyrazy kontekstowo oznaczające miejsce pobytu bohatera. Ich odnotowanie jest ważne dla badania idiolektu pisarza. Taką nazwą, oprócz wymienionych, jest także fort, który w tekście oznacza mieszkanie Piotra Rozłuckiego. Autorka opracowania wyłącza jednak tak nietypowe miejsca przebywania, nawet jeśli było długotrwałe, jak wagon w pociągu repatriacyjnym czy kajuta na okręcie, ponieważ nadrzędna jest ich przynależność do pola; 'środki transportu', wybiera natomiast z tekstów określenia wartościujące: takie, w których składnik emocjonalno-oceniający należy do znaczenia bądź wnoszony jest przez formant: barłogowisko, jama, legowisko, zamkowiszcze i nacechowane stylistycznie: kleta, sklecenie.

Przykład tych dwóch tomów dowodzi, iż niektóre leksemy nastręczały autorom sporo problemów klasyfikacyjnych. Zdarza się też, iż w części słownikowej poszczególnych monografii niektóre leksemy się powtarzają. Widać to choćby już na materiale kręgów tematycznych dom i przestrzeń. Wprawdzie zakresy materiału kręgów tematycznych 
dom i przestrzeń starano się rozgraniczyć według kryterium inwentarza pojęć antropologii kultury i geografii humanistycznej: dom odpowiada miejscu, które jest „udomowioną częścią przestrzeni”, a wszystko pozostałe należy do przestrzeni. Mimo to $\mathrm{w}$ obu pracach powtórzyły się niektóre leksemy - jednak w odmiennych użyciach i kontekstach, np. budynek - tylko w lp., przen. 'zwarty, wysoki, bujny las' oraz budynek 'to co jest wybudowane: dom, pomieszczenie, gmach' czy też: pieczara 1. 'jama, wgłębienie w ścianie' a) 'pochodzenia naturalnego', b) 'wykonane przez człowieka' oraz 1. 'jama powstała w skale na skutek ruchów górotwórczych lub działania wody, wiatru itp.'; 2. 'tu: ruiny, lochy zamku, podziemia; chwilowe miejsce schronienia', osiedle 1 . 'nieduże skupienie siedzib ludzkich', 2. tylko lp. przen. 'wspólnota ludzi połączonych podobnymi dążeniami, postawami, wyznawanymi wartościami', ale 'na wsi: dom mieszkalny wraz z zabudowaniami gospodarczymi; zagroda', państwo 1. 'terytorium objęte jedną władzą zwierzchnią, stanowiące całość polityczną; kraj', fraz. Państwo ciemności, państwo podziemia, państwo umarłych, 'kraina, w której przebywają umarli', ale 'wielkie dobra ziemskie, posiadłość, majątek, klucz', dziura tylko w lp. lekcew. 'mała, pozbawiona atrakcji miejscowość na prowincji' , lecz 'źle urządzony, zaniedbany lokal; tu również: miejsce chwilowego schronienia, nora'.

Autorką tomu Świat dźwięków jest Barbara Bartnicka. Słownictwo odnoszące się do świata dźwięków w tekstach St. Żeromskiego zajmuje ważną pozycję, zarówno pod względem liczby poszczególnych wyrazów, ich różnorodności, jak i pod względem częstości ich użycia. Słownik wyrazów nazywających dźwięki liczy ogółem 1326 haseł, w tym: 592 hasła rzeczownikowe, 502 czasownikowe, 153 przymiotniki, 53 przysłówki, 26 wykrzykników dźwiękonaśladowczych. Częstość użyć poszczególnych wyrazów związanych ze światem dźwięków waha się od ich pojedynczych poświadczeń (np. kwakać, sztajerek, wirtuoz, lirnik) aż do liczby 558 poświadczeń form czasownika styszeć, zajmującego pierwsze miejsce na liście rankingowej.

Łączna liczba zgromadzonych przykładów użyć badanego słownictwa przewyższa 18000. „Na podstawie tej kartoteki ekscerpowanych wraz z kontekstami wyrazów można było ustalić definicje znaczeniowe, dobierać do nich odpowiednie ilustracje cytatowe i badać łączliwość leksykalno-składniową wszystkich wyrazów" (s. 7). 
W słownictwie dotyczącym świata dźwięków wyodrębniono i opisano wiele grup znaczeniowych takich, jak: 1) wyrazy odnoszące się do percepcji słuchowej bohaterów oraz narratora np. słuchać, słyszeć, nastuchiwać, 2) wyrazy odzwierciedlające proces rozchodzenia się zjawisk akustycznych w ośrodku fizycznym, np. a) inicjowanie drgań fali głosowej wywołanych przez czynności podmiotu działającego, którym może być człowiek lub ciało wprawione w ruch przez siły przyrody, czy też urządzenia mechaniczne, np.: brzęknąć ostrogami 'sprawić, żeby ostrogi zaczęły brzęczeć, wydały brzęk', zagrzmieć 'zacząć grzmieć', zagwizdać 'zacząć gwizdać', zadzwonić do drzwi 'nacisnąć guzik dzwonka, żeby zaczął dzwonić' itd. b) fazę trwania dźwięku, rozprzestrzenianie się fali głosowej w powietrzu nazywa liczna grupa czasowników, np. terkotać, piszczeć, trzaskać, skomleć itd. czy też brzmieć (brzmiały akordy), rozlegać się (rozległo się chrapanie), panować (panowało milczenie) itd. c) fazę słabnięcia, zanikania dźwięku, np. cichnać, ścichnqć, słabną́, milknqć, ustawać. d) ostateczną fazę końca brzmienia dźwięku, np. ucichnąć, umilknać, ustać; 3) wyrazy nazywające stany ciszy i milczenia, np. milczeć, przycichnąć; 4) nazwy głosów i odgłosów (najliczniejsza grupa): a) związana z muzyką: nazwiska kompozytorów wymienionych w tekstach, np. Bach, Brahms, Schuman, Chopin, Wieniawski itd., nazwy wykonawców: akompaniatorka, dobosz, dudarz, rzępoła, wirtuoz itd.; nazwy zespołów, np. chór, kwartet, orkiestra, kapela itd. nazwy instrumentów, np. bałałajka, harfa, ligawka, szpinet, tołumbas, piszczałka itd.; nazwy części instrumentów, np. gryf, klawisz, smyczek itd.; nazwy form muzycznych, np. dumka, preludium, oberek, wywi jasy itd.; słownictwo związane $\mathrm{z}$ teorią muzyki np. akord, ef-mol, modulacja, nuta itd. b) nazwy głosów i odgłosów wydawanych przez człowieka, np. za pomocą organów i części ciała np. przez układ oddechowy, np.: bełkotać, kichać, kasłać, kłapać itd. dźwięki wydawane za pomocą nóg, np. ciapać, kłapać, szurać itd.; dźwięki wydawane za pomocą rąk (i niekiedy także trzymanych w nich narzędzi), np. bić, walić, kłuć, pukać itd. c) wydawanych przez zwierzęta, np. beczeć, skrzeczeć, miauczeć, gęgać, skomleć itd.; d) będącymi wytworami sił przyrody, np. szeleścić, grzmieć, świstać, zawodzić, dać itd.; e) dźwięki wydawane przez wodę, np. chlupać, kapać, szemrać, pryskać, kipieć, pluskać itd.; f) wydawanych przez uprząż, pojazdy konne, pojazdy i urządzenia mechaniczne, np.: terkotać, dudnić, 
skrzypieć itd. Słownictwo odnoszące się do dźwięków pełni w utworach pisarza różnorodne funkcje. Wyraźnie widać to w części interpretacyjnej monografii. I tak, leksyka ta może stanowić realistyczny składnik opisu wydarzeń, które decydują o rozwoju akcji utworu, bywa składnikiem opisu tła wydarzeń. Nazwy dźwięków i odgłosów zwłaszcza wywoływanych przez siły przyrody występują często $\mathrm{w}$ partiach powieści jako tło harmonizujące $\mathrm{z}$ odczuciami bohaterów, a także pojawiają się jako substytuty nazw uczuć, którym podlegają bohaterowie powieści.

Swoistą cechą języka Żeromskiego jest chętnie przez niego stosowany zabieg używania niezwykłych, nieszablonowych połączeń wyrazowych. Cechę tę autorzy monografii starali się uwypuklić w słowniku, wprowadzając poza cytatami ilustracyjnymi poszczególne znaczenia wyrazu hasłowego wszystkich jego połączeń walencyjnych. Uwzględniona $w$ ten sposób i zasygnalizowana została zarówno walencja składniowa, jak i leksykalna omawianych haseł.

Monografię dotyczącą Świata barw opracowała Kwiryna Handke. Podstawą materiałową jest zbiór nazw i określeń barw z całego kanonu uwzględnionych tekstów pisarza. Ekscerpcja tekstów objęła wszystkie użycia poszczególnych wyrazów $w$ formie podstawowej i w zależnych formach gramatycznych, które wyodrębniono jako jednostki słownikowe określające barwę. Ekscerpcja selektywna (w całym korpusie tekstów) dotyczyła leksemów: barwa i kolor oraz części leksemów pola światłocienia: świecić, płonać, płomień, ogień - jeżeli były związane z kolorem opisywanego obrazu. Przy tym zastosowano rozróżnienia: jeśli leksemy barwa $i$ kolor wprowadzały nazwy barw (np. barwa czerwona, o kolorze żótta), wówczas ekscerpcja była kompletna, w pozostałych wypadkach selektywna.

Materiał słownikowy został przedstawiony gniazdowo, a nie w jednym ciągu alfabetycznym. Na pierwszy plan wysunięto te najliczniejsze, tj. pole bieli i pole czerni, oraz towarzyszące im pole szarości, dalej układ zachowuje porządek widma optycznego, a więc: pole fioletu, pole błękitu, pole zieleni, pole żółci i pole czerwieni, w dalszej kolejności znalazły się: pole brązu, pole złota, pole srebra oraz pole światłocienia.

W obrębie pól nazwy barw zostały ułożone alfabetycznie. Wewnątrz gniazd leksykalnych (np. biały, bielszy, białawy, bieleć...) przyjęto 
następujący porządek gramatyczno-słowotwórczy: podstawowe formy przymiotników w kolejności grup według liczby i rodzaju gramatycznego; potem formy przymiotników w stopniu wyższym i najwyższym; dalej derywowane formy przymiotnika; formy przysłówka; złożenia; formy rzeczowników w układzie alfabetycznym, oraz formy czasowników, najpierw podstawowe, następnie kolejno z przedrostkami (z wydzieleniem form imiesłowów).

Obrazy hasłowe we wszystkich znaczeniach są obszernie ilustrowane. Jako podhasła podawane są ciągi połączeń wyrazowych, np. po haśle zielony następuje ciąg: drzewa, dzieci..., z towarzyszącą lokalizacją tekstową, a w wielu wypadkach również z cytatami, np. zielone fale morza Wspom 65, zielone jabłka Dzien.II 367, zielone jeziora Pop II 95,... zielone ognie - „Podniósł głowę płonaca $w$ ogniach niebieskich, zielonych, fioletowych, szkarłatnych $i$ jąt patrzeć dokoła" Pop I 114 itd. Ze względu na ogromne bogactwo zgromadzonego materiału językowego dotyczącego świata barw (ponad dwanaście tysięcy zapisów), a zarazem ograniczone rozmiary opracowania, zrezygnowano z ilustrowania cytatami tych zapisów, które nie wnoszą istotnych danych językowych czy stylistycznych. W takich wypadkach informuje się o liczbie ich użyć we wszystkich tekstach, bądź stosuje kwalifikator: częste.

W materiale znalazły się też niektóre wyrazy zawierające element kolorystyczny jedynie w znaczeniu etymologicznym, dziś zleksykalizowanym, jak, np. białko oka czy tęczówka oka.

Dla zwrócenia uwagi na charakterystyczne zjawiska w pisarstwie Żeromskiego zastosowano przed niektórymi cytatami kwalifikator sic!, np. brunatny r.ż. lm - barwy sic! - "Czerwone, rdzawe, brunatne, jasnożótte i płomieniste barwy okryły park przecudny”, sic! - "Czerwone, rdzawe, brunatne, jasnożótte i płomieniste barwy okryły las liściasty".

Uzupełnieniem przedstawienia gniazdowego jest alfabetyczny wykaz słownictwa określającego barwy. Każdy wyraz jest opatrzony kwalifikatorem gramatycznym, wskazującym liczbę i rodzaj danego leksemu w tekstach.

W omówieniach i dwóch tabelach przytoczono dane liczbowe pokazujące stopień nasycenia barwami w poszczególnych utworach oraz różnice w liczebności poszczególnych barw. Podawane w słowniku dane liczbowe mają przede wszystkim charakter orientacyjny i porów- 
nawczy (nie ściśle frekwencyjny czy statystyczny). Idzie tu o zaznaczenie częstotliwości występowania poszczególnych nazw i określeń barw oraz podkreślenie dysproporcji w pojawieniu się zwłaszcza niektórych, np. w całym zbiorze kolor czarny ma 1436 zapisów, a np. kolor turkusowy tylko 1 zapis.

W słownictwie z zakresu świata barw ważne są: sposób pokazywania przez Żeromskiego w tekście obrazów świata oraz środki językowe, jakich do tego używa, a więc nie tylko nazwy konkretnych barw i ich ocieni, ale także operowanie światłem i cieniem, barwą bądź jej brakiem.

Autorem monografii dotyczącej słownictwa z zakresu Walka, wojna, $i$ wojskowość jest Ryszard Handke. Część słownikowa uporządkowana alfabetycznie ma charakter indeksu rzeczowego militariów występujących w tekstach pism Żeromskiego i poprzedzona jest szeroko rozbudowaną częścią interpretacyjną. Podstawą opracowania są teksty zawierające słownictwo związane $\mathrm{z}$ walką, wojną i wojskowością, a zwłaszcza te, $w$ których występuje ono $\mathrm{w}$ związku $\mathrm{z}$ tematem utworu licznie, a także pojawia się, np. w epitetach, porównaniach, czy przenośniach.

Militaria prozy Żeromskiego są omawiane w porządku chronologii okresów historycznych, do których odnoszą się przywołane w tekstach realia. Wyróżniono zatem: epokę staropolską, epokę napoleonską, okres zaborów i wielką wojnę. W każdej z nich omówiono tylko wybrane utwory, wybitne i charakterystyczne, by ograniczyć powtórzenia. Najobszerniejszy i najbardziej zróżnicowany jest materiał dotyczący doby napoleońskiej, natomiast „ważnym i zarazem trudnym problemem interpretacyjnym okazała się terminologia wojskowa ostatniego z opisanych przez Żeromskiego okresów, ponieważ przy braku polskich nazw rodzimych pisarz w wielu wypadkach musiał je tworzyć" ${ }^{\prime}$. Na przykład: Statek, choć w innym opowiadaniu cyklu występuje poprawny nazewniczo okręt wojenny, przypomina cywilnemu prezentatorowi „hermetycznie zakorkowaną butelkę" - czytelnikowi, jeśli w ogóle przypomina cokolwiek, jest to przypadkowe, niezborne i całkowicie nieprzydatne do wytworzenia wyobrażalnej całości. Autor stanął

4 Por. K. Handke, Stownictwo..., s. 17. 
przed zadaniem podobnym do kreacyjnych kłopotów autorów literatury science fiction i wywiązał się z niego na miarę możliwości. Wśród nazwań, które utrudniają skojarzenia z wyobrażeniem obiektu są: „izba załogi", "nazwa centralna" - odpowiadająca głównej centrali dowodzenia, "skrytka oficerska”, a w niej zapewne „łóżeczka oficerów” - deminutivum związane $\mathrm{z}$ ciasnotą pomieszczeń, ale konotacyjnie fatalne, "gabinet dowódcy - zaznaczający stosowne wyobrażenie rozmiarów pomieszczeń, wreszcie „kotłownia” bez kotłów, przy czym nazwany "gazowym" napęd kazałby raczej mówić o maszynowni, ale tu zadziałało nieadekwatne przyzwyczajenie nazewnicze (s. 113). „Oglądał okiem znawcy i poskromiciela owe wewnątrz statku dzikie zwierzęta uśpione, które drzemały posłusznie, gotowe ocknąć się i wybuchnąć na każde jego skinienie w głębokości siedmiu metrów pod wodą. Wiele wskazuje, że mowa tu o torpedach (...) Kombinacja zmyśleń i informacji wskazuje jednak, że autor jakimś źródłem wiedzy dysponował sumiennie, choć nie zawsze kompetentnie. Torpedy nie wybuchały na skinienie, lecz zaledwie były wystrzeliwane i procent wybuchnięć w wyniku trafienia wcale nie był imponujący. Imponowała jednak sama broń i poruszając wyobraźnię pisarza, czyniła w nich trochę zamętu" (s. 112).

W poszczególnych szkicach monograficznych dla większej przejrzystości uwzględniono dwa gniazda tematyczne: Broń i środki walki. Użycie broni - walka indywidualna. Starcia zbiorowe - aspekt taktyczno-strategiczny. Dowodzenie, określenie podległości - dowódcy uosabiający odziały. Okropności i następstwa wojny. Ewidencja sił - ordre de bataille, formacje i odziały wojsk - nazwy jednostek. Sztuka fortyfikacji. Obiekty wojskowe. Realia życia wojskowego - powszedniość i ceremoniały. Stopnie i funkcje wojskowe - przynależność do rodzajów broni. Umundurowanie, dystynkcje. Oporządzenie i sprzęt wojskowy. Fachowa terminologia wojskowa. Komendy i zwroty regulaminowe. Żargon wojskowy. Obce wpływy językowe. Wyrażenia nabierające znaczenia militarnego $\mathrm{w}$ kontekście. Stylistyczna i stylizacyjna funkcja leksyki militarnej. Tradycja i etos.

Słownictwo z kręgu Myśli $i$ mowy autorstwa Henryki Sędziak odznacza się dużą frekwencją i w większości wypadków bogatą treścią znaczeniową, zwłaszcza czasowniki i rzeczowniki charakteryzują się wieloznacznością. W słowniku uwzględniono wszystkie wyrazy od- 
noszące się do myślenia i mowy, a także ich znaczenia, które są poświadczone w tekstach Żeromskiego.

Poszczególne znaczenia omawianych leksemów ilustrowane są na ogół trzema cytatami, tylko przy dużej liczbie wystąpień danego leksemu - pięcioma. Mniejsza liczba cytatów (1-2 cytaty) wskazuje na ogół pełną liczbę użyć danego wyrazu w utworach pisarza. Czasami rezygnowano $\mathrm{z}$ drugiego, trzeciego cytatu, jeżeli wystąpił on $\mathrm{w}$ innym artykule hasłowym. Cytaty niekiedy powtarzają się, a dzieje się tak wówczas, gdy $w$ jednym zdaniu występują wyrazy pojawiające się $\mathrm{W}$ analizowanym materiale sporadycznie, $\mathrm{np}$. hałasować, przebtaganie (Uciek 194), pozywanie i zaprzysieganie (Pop I 158), ślubowanie i wyrzut (Syz 117) itd.

$\mathrm{W}$ opracowaniu znalazły się wyrazy związane z myśleniem, mową i słownictwo łączące elementy mówienia i myślenia. Wśród nich autorka wyróżnia wyrazy potoczne i nacechowane środowiskowo, np. bajtlować pot. 'gadać dużo i bez logicznego związku; pleść, paplać', jojczyć posp. 'narzekać w sposób nużący otoczenie; biedolić'; sobaczyć posp. 'wymyślać, kląć, besztać'. Są także wyrazy dawne i przestarzałe, np. egzageracja, przestarz. 'przypisywanie czemuś zbyt wielkiego znaczenia, przesada', szydność, daw. 'szydzenie, szyderstwo', niezbłagany, daw. 'nieubłagany', neologizmy i indywidualizmy, np. hergotać 'mówić po niemiecku, powtarzać Herr Gott', marzenięta iron. 'marzenia' itd.

W monografii zebrano materiał językowy obejmujący 2093 samodzielne znaczeniowo jednostki leksykalne stanowiące $\mathrm{w}$ słowniku wyrazy hasłowe. Jest to leksyka $\mathrm{z}$ wielu różnych kategorii słownictwa: 1) czasowniki myślenia: a) leksemy poznania, np. badać, dumać, myśleć, rozważać; b) leksemy pamięci, np. pamiętać, rozpamiętywać, wspominać; c) leksemy planowania, np. planować, projektować, zamierzać, i związki frazeologiczne: ani myśleć, powziqć zamiar (decyzję) i in. Czasowniki mówienia: a) komunikować słowami: mówić, gadać, gawędzić, rzec, wołać i in. b) czasowniki z komponentem 'mówić' błagać, błogostawić, chwalić, prosić, i in. c) czasowniki tylko kontekstowo nazywające czynności mówienia: cedzić, ciagnąc, syczeć, wykrztusić i in. czasowniki łączące elementy mówienia i myślenia: a) leksemy wyróżniające mówienie wraz z czynnością mentalną, np. akceptować, dociekać, stwierdzać, b) leksemy zawierające odrębne znaczenia obejmujące czynność mentalną i czynność 
mówienia, np. wspominać, wymyślać; c) wyrazy, których odmienne znaczenie pojawia się we frazeologizmach, np. podchwycić, zdawać, znać. 2) rzeczowniki: a) nazwy pojęć, np. myśl, pamięć, rozum, słowo, uwaga; b) nazwy wykonawców czynności, np. myśliciel, mówca, rozmówca; c) nazwy czynności i procesów, np. myślenie, przypuszczenie, wyznanie; d) nazwy obiektów czynności, np. domyst; e) nazwy rezultatów czynności i procesów, np. mowa, rada, kłamstwo; 3) przymiotniki oraz imiesłowy przymiotnikowe, np. kłótliwy, gadatliwy, myślowy, oraz zamyślony, skłócony i głoszony; 4) przysłówki, np. bezmyślnie, słownie.

Autorka podaje $\mathrm{w}$ tabelach frekwencję poszczególnych części mowy. Największą odznacza się słownictwo związane z mówieniem (72,9\% analizowanego materiału słownego). W zebranym słownictwie dominują czasowniki, które stanowią łącznie 57,1\% omawianego słownictwa, rzadziej występują rzeczowniki $(33,9 \%)$. Niewiele jest przymiotników $(4,5 \%$ wyrazów hasłowych) oraz przysłówków $(2,3 \%)$ i imiesłowów $(2,2 \%)$.

Ta warstwa leksyki wymagała od autorki szczególnie wnikliwej interpretacji leksykologicznej i rzetelnej analizy semantycznej, a także uwzględnienia teorii aktu komunikacji językowej.

Sześć monografii poświęconych słownictwu pism Stefana Żeromskiego, które otrzymaliśmy, uświadamia ogrom trudu, podjętego przez autorów, by jak najlepiej przedstawić znaczenia słów, by zdać sprawę z niezwykłości języka i myśli Stefana Żeromskiego. O rozmiarach pracy dają wyobrażenie źródła ekscerpcji (ponad 40 tomów tekstów Stefana Żeromskiego). Przedstawiony materiał ma trudną do przecenienia wartość filologiczną. Otrzymujemy bogaty materiał przykładowy poparty bardzo rzetelną analizą językową.

Każdy tom monografii jest dziełem indywidualnym i specyficznym ze względu na sposób uporządkowania i opracowania zgromadzonego w nim materiału językowego. Odbiorca otrzymuje informacje słownikowe i interpretacyjne. Opracowanie leksykograficzne wyrazów hasłowych może być bardzo przydatne w badaniach różnego typu, zwłaszcza stylistycznych. Opis semantyczny dąży do ukazania wielowymiarowości pojęć. Obraz łączliwości ujawnia ponadto fleksyjno-składniowe osobliwości idiolektu pisarza, a niekiedy tylko różnice między normą współczesną i dziewiętnastowieczną. Słownik ten oferuje czytelnikowi 
przemyślaną, opartą na świetnej znajomości całego materiału oraz języka i myśli Żeromskiego, interpretację istotnego fragmentu jego twórczości.

Jest to dzieło, którego odbiorcami mogą być bardzo różne kręgi osób: miłośnicy polszczyzny i twórczości pisarza, jej tłumacze, badacze, komentatorzy, historycy i teoretycy literatury, filozofowie, historycy, lingwiści, szeroki krąg ludzi interesujących się twórczością Stefana Żeromskiego, uczniowie, studenci oraz środowiska humanistyczne związane $\mathrm{z}$ różnymi dziedzinami nauki i kultury.

Książka została wydana bardzo starannie. Na okładce każdej z monografii zamieszczono odpowiednio dobraną do tematyki tomu, reprodukcję fotografii Moniki Handke.

Należy mieć nadzieję, że pozostałe tomy Stownictwa pism Stefana Żeromskiego trafią jak najszybciej do rąk czytelników. 